\title{
A Glimmer of Hope for Sulawesi
}

\author{
John Mackinnon
}

The wildlife of the island of Sulawesi in Indonesia is a remarkable mixture of Asian and Australasian forms, with many endemic species. But it is being rapidly destroyed as a result of timber logging, hunting and agriculture. However, Dr MacKinnon, who is manager for two World Wildlife Fund projects in North Sulawesi, believes that action now could save most of the larger animals. With Indonesia's new interest in conservation he is optimistic that this will be achieved.

Sulawesi, formerly Celebes, the central island of the Malesian archipelago, lies due east of Borneo. Its fauna, derived from both Asia and Australasia, is unique, but due to the island's remoteness has gone very much its own way. The resulting hotchpotch-monkeys with marsupial cuscus, jungle-fowl with megapode-includes an extraordinary list of endemic species. Groves lists 71 endemic mammals and Stresemann 84 endemic birds. ${ }^{1,2}$ Clearly Sulawesi is of enormous importance to the conservationist. But it has been badly neglected since the Second World War, and such fascinating creatures as anoa, babirusa, giant civet and maleo bird have become seriously endangered, while human expansion and increasing timber exports threaten the forest homes of all other wildlife. Hopefully the recent and continuing activities of FAO, WWF and the Indonesian Directorate for Nature Conservation are just in time to catch Sulawesi before there is a landslide of extinctions.

\section{Conservation Activities}

Until 1977, in the whole of Sulawesi, there was only one official of the Direktorat Perlindungan dan Pengawetan Alam (Nature Conservation), which is responsible for implementing the game laws and protecting nature reserves, and he was based in Manado on the northern peninsula. Now, however, there are plans to expand the Department considerably and form sections in central and south-eastern Sulawesi, and also to increase greatly the area of wildlife reserves. A few years ago Sulawesi's reserves totalled about 6000 ha; today, with the welcome addition in 1973 of the Lore Kalamanta Reserve in Central

\section{North Sulawesi}

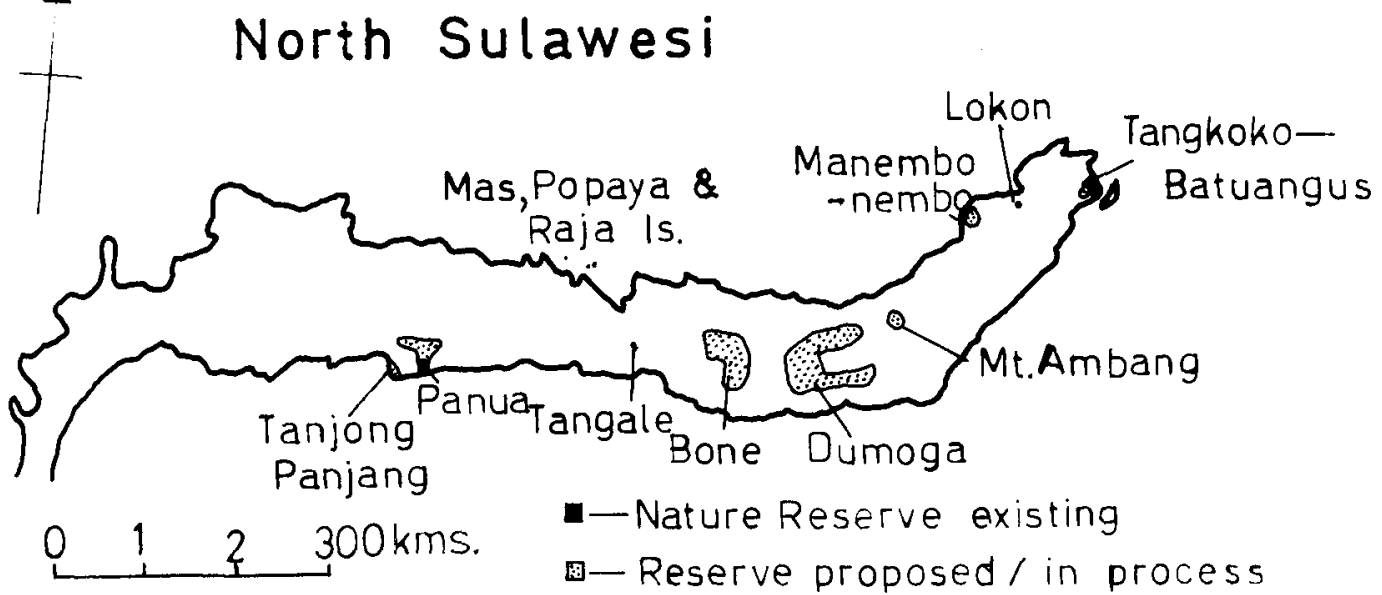


Sulawesi, the total is over $150,000 \mathrm{ha}$, and if all planned areas materialise this should rise in the next few years to over 600,000 ha. For the past four years the UNDP/FAO have been running a Nature Conservation and Wildlife Management Project in Indonesia, headed by John Blower, which helps PPA in the selection of new conservation areas, the production of more effective streamlined legislation and the writing of reserve management plans. In Sulawesi the team has been particularly active in proposing extensions and writing the management plan for Lore Kalamanta, and looking for a new reserve in the south-east.

WWF has three projects in Sulawesi as part of its extensive Indonesian programme, one of which is to develop Lore Kalamanta. The other two are for conservation management of north Sulawesi in general and the TangkokoBatuangus reserve in particular, and it is with these two that $I$ am involved as project leader, assisted by my wife Kathy and an Indonesian counterpart Ir. Tarmudji.

\section{Wildlife in the North}

We have been horrified to see the pace of nature destruction in North Sulawesi. Timber logging, burning of new ladangs (clearings for cultivation) and extensive hunting by villagers have destroyed many fine areas including some small but unguarded nature reserves. Nowhere have I encountered people with such a wide food range expending so much effort on trapping bats, rats, snakes, squirrels, birds, cuscus, pigs, deer, anoa, etc., for food. Nevertheless most of Sulawesi's larger fauna survives and can be salvaged if conservation measures are taken in time.

Lowland Anoa Bubalus depressicornis. Near towns and villages where it is heavily hunted and snared, the anoa has disappeared or reached low numbers in many places, but healthy populations do occur in large forest blocks.

\section{LOWLAND ANOA}

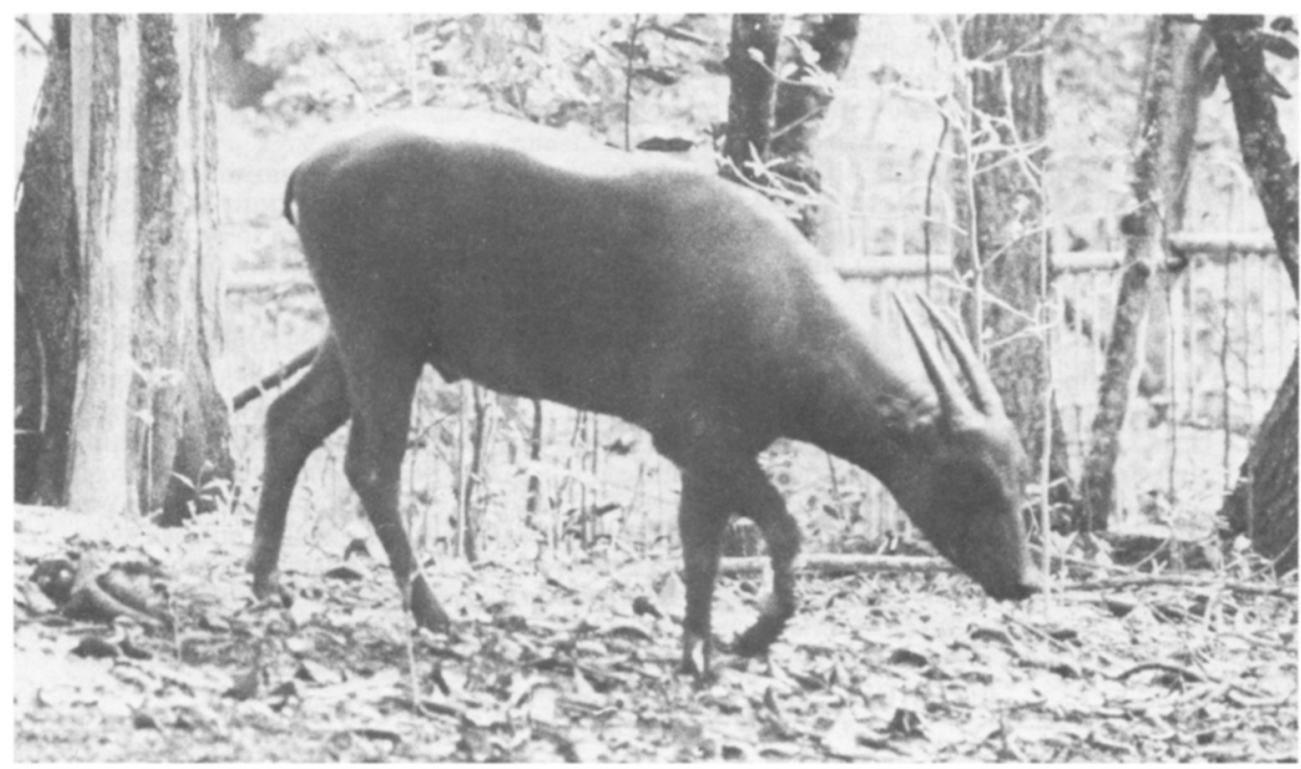




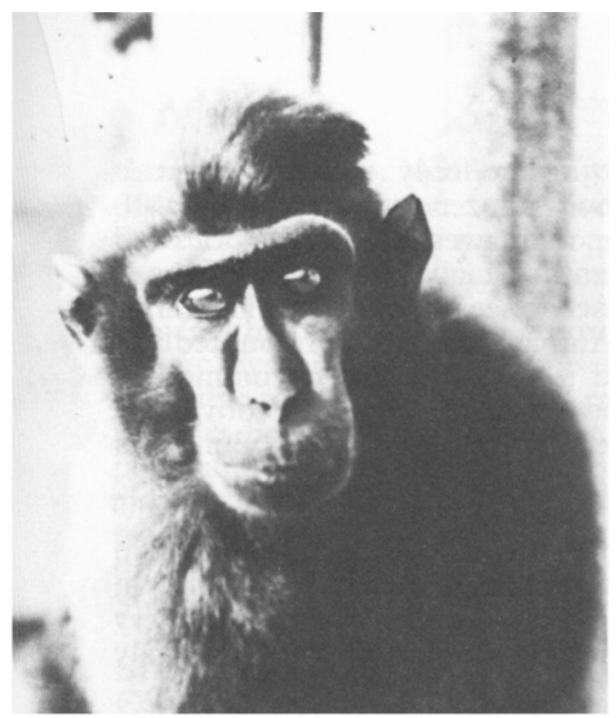

CELEBES BLACK APE

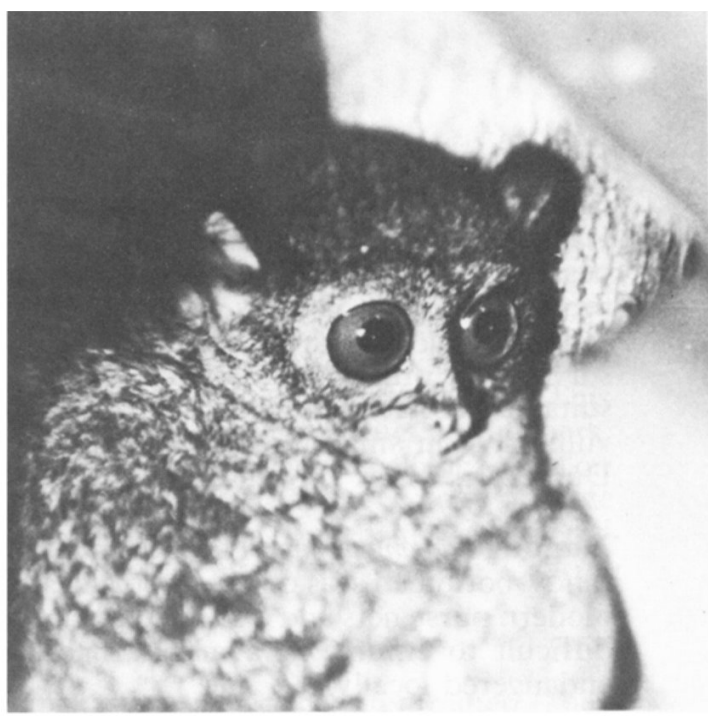

CELEBES TARSIER

Highland Anoa Bubalus quarlesi. Endangered. Always a rare animal, this anoa is known from specimens collected in scattered localities. We have found lowland anoa in highland areas where we presumed there should be the highland form, and I personally doubt the validity of this form as a distinct species.

Babirusa Babyrousa babyrussa. Endangered. This extraordinary endemic pig has disappeared from large areas of its former range. Having evolved in a more or less predator-free environment, and because of its low recruitment rate (only two young at a time), it is highly vulnerable to all hunting pressures. Good populations still occur in remote forests where human activities are slight or recent, and also in Muslim pockets of this predominantly Christian region.

Cuscus Phalanger ursinus and $P$. celebensis. Threatened. Both these marsupials are highly prized for meat and are trapped or hunted for food, but seem to survive in most forest areas.

Monkeys Macaca nigra, M. nigrescens and $M$. hecki (allopatric). All three macaques are heavily hunted as food and for pets, particularly near cultivated fields where they are regarded as pests. Very low densities are found over wide areas of forest, but surprisingly high densities are found in fruit-rich strongholds. $M$. nigra and $M$. nigrescens should be safe in proposed reserves. $M$. hecki is present in the Panua reserve but rare. It is yet to be seen how many occur in the proposed Panua extension.

Spectral Tarsier Tarsius spectrum. We have been delighted to find this tiny nocturnal primate wherever we have looked for it. Large healthy populations survive in all types of forest between sea level and $1500 \mathrm{~m}$ at densities up to eight animals per hectare. 
Giant Civet Macrogalidia musschenbroekii. The only endemic civet is extremely rare in museum collections; only about a dozen specimens exist in all. It is only recorded from the north-east corner of Sulawesi, although stories and possible sightings have been reported from central Sulawesi. As it had not been recorded here for 30 years, we were very pleased to see the animal at close range and find tracks and faeces in the Mount Ambang reserve. Undoubtedly it survives in other mountainous regions and is probably not uncommon in suitable habitat, but being at the top of the local food chain it is obviously vulnerable in small reserves. The giant civet should be safe when Bone and Dumoga reserves are established.

Dugong Dugong dugon. This delightful sirenian is still described as common in sandy-bottomed seas off the north coast. But dugongs are frequently caught in modern purse nets and exhibited as curiosities until they die. Protection is very difficult to enforce in a marine habitat, and the animal remains seriously endangered locally.

Green and Hawksbill Turtles Chelonia mydas and Eretmochelys imbricata. There are big concentrations of these turtles. Both nest on sandy beaches along the north coast, but almost all eggs are stolen by fishermen, even on two island reserves, Mas and Popaya, and adults are frequently harpooned at sea. Both species are locally endangered.

Reticulated Python Python reticulatus. Always killed for its meat or skin when encountered, the python nevertheless remains common in most forests due to the unusual abundance of rats (40 species!) in Sulawesi. Apparently there are several records of attacks on humans by large specimens. This is theoretically possible because lack of medium-sized terrestrial mammals in Sulawesi forces large snakes to graduate direct from rat-size prey to pig size.

Hornbills Aceros cassidix and Penelopides exarhatus. Both birds are common in lowland forests despite regular hunting for food and pets. Aceros, the larger, is very spectacular.

Maleo bird Macrocephalon maleo. Seriously endangered. This handsome black and white megapode is very vulnerable because of its communal nesting habits. Eggs weighing $230 \mathrm{gm}$ are too great a temptation for villagers to resist, and the bird is heavily persecuted and extinct in some former haunts. Protection enforcement measures are urgently needed.

There is a long list of endemic rats, bats and small birds that are threatened by the deforestation and human expansion, but they should survive in all sizeable blocks of forest that can be preserved.

\section{Expansion of Reserve Areas}

The enlightened attitude of local government has been a pleasant surprise, and we have had discussions on the need to conserve greater areas of natural habitats and the role of wilderness in preserving climate, soils and water drainage patterns as well as its importance for touristic, recreational, educational, research and aesthetic values. As a result we have been able to help PPA in its applications for new reserves; both existing and planned reserves are 
shown on the map. Most exciting of all is the large 200,000 ha Dumoga reserve which has already been approved by the governor of the province and is scheduled to become a national park. This will protect some beautiful forests from $200 \mathrm{~m}$ up to $1700 \mathrm{~m}$, all almost totally unspoiled by man.

\section{Research Activities and Requirements}

In our own project and also in separately sponsored parallel studies, we have been able to indulge in a useful range of conservation-oriented research. This includes behavioural and ecological studies of crested macaques and tarsiers, population studies on maleo birds, and collection of various ecological data on many other animals. More research will be needed on the ecology of large mammals, especially babirusa and anoa. Guy Musser has recently completed three years basic research on small mammals, especially rats, in Central Sulawesi.

\section{Staff and Education}

Conservation staff are to be increased in numbers and also better trained. They will take courses on wildlife management at Bogor and also benefit from their engagement in the FAO and WWF projects with overseas scientists, all of whom work in close cooperation with Indonesian graduate counterparts. It is also hoped that some of these counterparts can go on to fellowship courses abroad to gain diplomas in wildlife management.

WWF has a long-term conservation education programme directed from Bogor and aimed at promoting nationwide a better understanding, awareness and appreciation of nature. In addition we are starting a small local scheme in which Indonesians take a travelling slide show of the region's wildlife from village to village, explaining conservation needs and laws to the people who live close to the forest.

It will take years, probably decades, to judge the success of the new efforts at conserving Sulawesi's unique wildlife. Certainly there are many problems and many uncertainties. But it is exciting that efforts are being made, some change in outlook is being achieved and the right line of action being considered. It gives as much room for optimism as we dare expect.

\section{References}

1. GROVES, C.P. 1976. The origin of the mammalian fauna of Sulawesi (Celebes). $Z$. Säugetierkunde 41: 201-216.

2. STRESEMANN, E. 1941. Die Vögel von Celebes, F. Orn. 89 1:1-103.

Dr John MacKinnon, C/o WWF, J1. Juanda No 9, Bogor, Java, Indonesia.

\section{Manatees in Suriname}

In Suriname the manatee Trichechus m. manatus, once abundant, is the most endangered large mammal, say Nicole Duplaix and Henri A. Reichart following their recent survey. They estimate the population at probably not more than 500-600, and its future uncertain, despite the fact that manatees are fully protected and that 'Suriname boasts probably the best nature protection system in South America'. Unfortunately the quarter of the country that is inhabited (population only 383,000) is also the area of the animal's distribution. Manatees are sometimes caught in nets and also struck by boats, the latter a problem likely to increase. The authors believe that the creation of 'special management areas', which new legislation is likely to permit, could be the best hope for the manatees. 